\title{
SECOND ALBINO GREAT GRAY OWL SIGHTED IN MANITOBA
}

\section{GEORGE HOLLAND, 129 Burlington Way, Winnipeg, Manitoba. R3Y 1C1}

In spite of the harsh weather conditions on Saturday, 28 December 1990, Eric Cole, Bruce Foutch and I decided to spend the day birding in the boreal forests north of Winnipeg. The temperature was $-32^{\circ} \mathrm{C}$ and the northwesterly winds combined with the temperature to give a windchill of 2150 .

At $0938 \mathrm{~h}$, we noticed a large white owl perched about six metres above the ground in a deciduous tree somewhat in the open at the junction of Highway 59 and Provincial Route 319, the latter road leading to Patricia Beach. We were astonished to find that the bird was a Great Gray Owl, recognized as such by its large size, Great Gray facial disc which was of normal colouration, its yellow eyes and its lack of "ears". But for the facial disc, the owl was completely creamy to pure white. The creamy colouration surrounded the facial disc, extended over the shoulders and gradually melted into white on the primaries and tail feathers. There were no other coloured markings discernible on the owl. The feathers were somewhat ruffled against the cold and gave the owl the appearance of being larger that normal. Unfortunately we did not have a camera with us, but we did observe the bird for at least 6 minutes before we moved on. It responded to "pishing" by turning its head in our direction, but otherwise gave us little notice.

The following day in mid-moming the bird was observed briefly by Diane Kunee and Robert Nero. They found the bird about two $\mathrm{km}$ south of where we had seen it. They were able to see the dark face on an otherwise all-white body, though they viewed the owl at a distance of about $150 \mathrm{~m}$. Bob admits it was an impressive sight. Bob also informs me that this bird was distinctly different from another albino photographed at Norway House [see "White Great Gray Owl" in this issue].

The feelings the owl conjured up in me will leave a lasting impression. I could visualize only getting a glimpse of this bird, as it retired into the surrounding forest of snow-covered black spruce and tamarack, and then being forever mystified as to its identity. If only because of this sighting, I now share a little more of the reverence Indians have always held for wild creatures, in particular, owls.

Some places are like great outdoor mansions in which we wander from room to room.

F. Lehrman. 1988. The sacred landscape. Celestial Arts, Berkley, CA. 